\title{
The Notwithstanding Clause and the New Populism
}

\author{
Richard Mailey
}

\section{Introduction}

The following article asks whether the notwithstanding clause contained in Canada's Constitution Act, 1982 [Constitution Act] ${ }^{1}$ remains defensible where populists are in power. It ultimately dismisses two conventional justifications of the clause - one based on a principle of interinstitutional dialogue, one based on a majoritarian principle of legislative supremacy - before briefly considering possible amendments to the clause that may render it justifiable in a populist context (or more generally, where the political convention against using section 33 substantially weakens).

\section{Section I: Populist Chaos?}

I am sometimes hesitant to quote Carl Schmitt, but it seems appropriate, when considering the contemporary defensibility of the Constitution Act's notwithstanding clause, to begin with a reference Schmitt's famous claim in Political Theology that " $[\mathrm{t}]$ here exists no norm that is applicable to chaos." What this means, as Schmitt explains, is that the applicability of a legal norm ought to depend in the final instance on the persistence of a "normal"3 situation that allows for its justification. More simply, the relevant question is: are circumstances such that the rule or norm continues to do something, i.e. maintains a connection to a legitimate social purpose? With this question close in mind, this article suggests that the rise of populist politics in Canada could eventually create a situational shift that would deeply under- mine traditional justifications of the section 33 clause. Before I get there, though: what exactly do I mean when I use the term, "populism"?

In arriving at a cursory, working definition of the so-called "new" populism that has been sweeping the Western world of late, one needn't look too far beyond Jan-Werner Müller's recent and oft-cited monograph, What is Populism?5 For Müller, while the word "populism" obviously means vastly different things to different people (contrast Müller's definition with Barack Obama's, for example ${ }^{6}$ ), there are several features that are common to many of the movements and governments recently endowed with the label, such as the governments of the Law and Justice party (Poland), Nicholas Maduro (Venezuela) and Donald Trump. Above all, what links these governments and leaders is a professed sense that "they, and they alone, represent the people."7 The derivative positions that then stem from this conceited sense are: 1 ) a dedicated anti-institutionalism $^{8}$ (institutional checks will only obfuscate the leader's ability to authentically represent his or her people), and 2) a conception of "the people" that eschews the population as a whole in favour of a morally homogenous block of supporters, thereby making authentic representation appear possible (as Trump put it on the campaign trail, "the other people" - those people who don't support him - "don't mean anything"9).

Of course, one can debate the extent to which these tendencies have been exhibited by governments in Ontario ${ }^{10}$ and other provinces. However, rather than getting sidelined with this 
otherwise important debate, I want to ask a more hypothetical question: namely, the question of whether the election of any government that fits Müller's definition would undermine conventional justifications of section 33 by functioning, in Schmitt's terms, as a "chaotic"11 disruption of democratic normality. With this question in mind, I will proceed below by examining and ultimately rejecting two possible justifications of section 33 in a populist context. The first is the dialogic justification originally put forward by Peter Hogg and Allison Bushell ${ }^{12}$ (before being adopted by numerous other scholars), and the second defends section 33 not because it balances institutional power or promotes interinstitutional dialogue, but because it strives to ring-fence or preserve the supremacy of legislative majorities in post-1982 Canada. Let's turn to the first, dialogic approach below.

\section{Section II: Section 33 as a Means of Promoting Inter-Institutional Dialogue}

As Richard Albert puts it, even if it is ultimately viewed as an almost defunct failure, the notwithstanding clause pursues a set of "laudable aims"13 - none more so, perhaps, than its attempt to "reconcile the tension between parliamentary sovereignty and judicial supremacy"14 by promoting a "dialogue" 15 between courts and legislatures over the interpretation of certain constitutional rights (specifically those contained in sections 2-7 and section 15 of the Charter). However, despite its influence on both constitutional scholars and the Canadian courts, ${ }^{16}$ there are good reasons for supposing that the dialogue metaphor - originally coined by Peter Hogg and Alison Bushell in the Osgoode Hall Law Journal ${ }^{17}$ - was from the start a decidedly imperfect way of describing the state of Canadian constitutional law post-1982. To begin explaining and defending this claim, it's worth initially flagging a point that was made cogently by Christopher P Manfredi and James B Kelly in a 1989 response to Hogg and Bushell's original article: namely, that the section of the Constitution Act that is the centerpiece of Hogg and Bushell's argument, section 1 as opposed to section 33 , actually has little to do with dialogue conceived as an exchange of views between equal partners. $^{18}$

Bear with me here, because this is extremely relevant to the role that section 33 needs to play in dialogic (or institutional "balancing"19) justifications of Canada's 1982 rejig of constitutional law. For most scholars who use the dialogue metaphor (e.g. Hogg and Bushell, Kent Roach ${ }^{20}$ ), section 33 is less important than section 1, since it is through the section 1 analyses of courts that legislators gain information on how they might "tweak" judicially invalidated legislation or legislative provisions to more finely and delicately balance their pursuit of important social goals with respect for fundamental rights (or more precisely, with judicial interpretations thereof). In one sense, the idea of legislators "tweaking" invalidated laws in light of a judicial opinion sounds a lot like a respectful dialogue, with legislators taking careful account of judicial opinions without disregarding their own priorities. However, in another, possibly more decisive sense, the dialogue that section 1 facilitates will often be one-sided or at least judicially-dominated, since it applies only where legislatures are willing to accept a judicial interpretation of constitutional rights in full. Indeed, according to Manfredi and Kelly, Hogg and Bushell sometimes seem to assume, problematically, that courts are exclusively competent to interpret constitutional rights. To quote:

The... most crucial... flaw in the normative argument [of Hogg and Bushell] is its assumption of a judicial monopoly on correct interpretation. [This] is reflected in the curious decision not to consider decisions to appeal as a form of legislative response that promotes dialogue. An appeal explicitly communicates a democratic actor's judgement that a judicial decision is wrong in some sense. By contrast, legislative sequels that merely incorporate a judicial interpretation into new law do not challenge the judicial interpretive monopoly. However, as Tushnet notes, the 'misplaced allocation of sole constitutional responsibility to the courts' debilitates democracy, even if legislatures can absorb judicially created norms into new statutes. Genuine dialogue only exists when legislatures are recognized as legitimate 
interpreters of the constitution and have an effective means to assert that interpretation. ${ }^{21}$

Where section 1 is in use, then, Manfredi and Kelly's claim is that judges will on balance reign supreme, with legislators taking on the arguably minor role of deciding how, but not whether, to tweak invalidated legislation in light of a judicial interpretation of constitutional rights. By contrast, section 33 empowers legislators to go a critical step further by also deciding whether invalidated legislation should be tweaked in light of a section 1 analysis or simply reenacted in a way that registers full-fledged disagreement with the judiciary on its interpretation of the relevant Charter rights (or on whether violations of interpreted Charter rights are proportionate). In other words, it is section 33, not so much section 1 , that potentially enables Canadian legislatures to participate in something approaching an equal dialogue over how constitutional rights should be interpreted, and the success of dialogic justifications of the Constitution Act settlement accordingly hinges - to a large extent, I think on the way that the section 33 clause functions.

So, how does section 33 function? The first, somewhat obvious point to make here is that there is an evident disjoint between the way that section 33 functions in practice and the way that it functions formally. In practice, as Richard Albert $^{22}$ and many others ${ }^{23}$ have pointed out, the strength of the political convention that quickly developed against invocations of section 33 has given some credence to arguments that the 1982 constitutional renovations gave rise to a situation of de facto "juristocracy" 24 in Canada, a situation where judges end up having final say on most issues of constitutional interpretation. However, formally, section 33 looks like a very different beast, since it gives the legal power of final say on specified questions of constitutional interpretation to legislative institutions (although of course not to any particular group of legislators, since uses of section 33 have to be renewed every five years, i.e. with an election between an initial invocation and its renewal).

The key point to make here is that the interaction between these two dimensions, the practical and the formal, has arguably produced a situation that is greater than the sum of its parts, although calling it a meaningfully "dialogic" situation may well be a stretch (as Manfredi and Kelly argue). To sum up this dynamic, the fact that the formally robust override powers of section 33 have been used infrequently represents their widely accepted and frankly appropriate status as constitutional "nuclear" 25 options, to be used only in rare instances where a legislative sequel that takes account of a court's section 1 analysis and fulfils key governmental objectives is not possible (or at least, is not perceived as possible by elected representatives). In this sense, the potential value of the notwithstanding clause is not so much that it allows for an ongoing conversation or dialogue, but that it explicitly deals (and strives to deal as democratically as possible) with the question of whose institutional will should prevail, in a constitutional democracy, where courts and legislatures disagree intensely and sincerely over how to interpret constitutional rights provisions.

While it is certainly admirable that the Canadian Constitution bucks the global trend ${ }^{26}$ of underemphasizing this question, its fusion of legal empowerment with political constraint can only work if a political culture prevails in which the override power is seen by enough relevant actors as an exceptional tie-breaking power (a power to be used "in rare instances" as I put it above). In this regard, while "even [the] most ardent supporters" of section 33 usually concede that "for constitutionalized rights to mean anything at all, the notwithstanding clause must be used rarely," ${ }^{27}$ the problem is that Müllerstyle populists reject this premise (and all such premises) by definition. Indeed, for such populists (and again, I am sidestepping the question of whether such populists are currently in power in Canada), their direct, almost mystical connection with the people - a connection that is ensured by their deeply problematic conflation of "the people" with "their supporters" - gives them the right and even the democratic obligation to take unilateral action on almost any issue, including by derogating openly and persistently from constitutional rights commitments.

In the US, for example, President Trump's emergency declaration to fund his Mexican bor- 
der wall ${ }^{28}$ represents a neat encapsulation of this logic, as do the attempts to capture constitutional and apex courts in states like Poland by changing their composition and/or voting rules. ${ }^{29}$ What typically justifies these tactics, as noted above, is a professed belief that the populist leader or government is alone capable of speaking authentically in the name of the people (as Müller put it, they believe that "they, and they alone, represent the people"30). Why, they wonder, should their power be checked or filtered - or even just exercised with a cautious concern for the interests and opinions of those who don't share their contestable political vision - when they, for all intents and purposes, are to be regarded as nothing less than "the people" incarnate?

\section{Section III: Section 33 as a Means of Preserving Legislative Supremacy}

If such attitudes were to become prominent in Canada or in one of its provinces (or if you believe that they already are), any semblance of balance that the notwithstanding clause currently promotes as an exceptional tie-breaking device would be at risk of withering away and ceding to a full-throated parliamentary and legislative supremacy of the type that the Charter was seemingly meant to stymie. Here, though, one may plausibly object that, far from marking a step away from legislative supremacy, the inclusion of section 33 powers in the Constitution Act in fact indicates an overriding intention (actual or merely apparent) not to delicately balance legislative and judicial power, but to preserve ${ }^{31}$ parliamentary and legislative supremacy while allowing courts to play an enhanced but still ultimately minor role in the protection of fundamental rights. If this is a plausible claim, then the election of populist governments would in theory pose far less of a threat to the proper functioning of section 33, since the judicious uses of override powers that are associable with populist ideology would then appear as a (perhaps regrettable) matter of institutional right - not as a disruption of any precarious institutional balance pursued by the Constitution Act. The question is: can section 33 be defended in this way?
As a first response to this question, one may note that the small group of provincial leaders who argued fervently for inclusion of the notwithstanding clause in the Constitution Act have often defended it along more or less these lines (i.e. by at least invoking the language of legislative supremacy). For example, the former premier of Alberta, Peter Lougheed, said the following in response to a question in Alberta's Legislative Assembly:

\begin{abstract}
The then premiers of Manitoba and Saskatchewan and the Premier of Alberta took the position in the constitutional discussions that we needed to have the supremacy... of the legislature over the courts. As I mentioned in the House on November 6, 1981, we did not [want] to be in a position where public policy was being dictated or determined by nonelected people. ${ }^{32}$
\end{abstract}

While this quote may lend some weight to a legislative supremacy defence of section 33, there are three points that effectively prevent such a defence from succeeding, in my view. Firstly, one shouldn't conflate the perspectives of the three premiers listed above with the perspectives of all of the Constitution Act's framers (even if those three premiers did end up getting Trudeau et al. to reluctantly accept the override). Secondly, Lougheed's stance is actually more complex and nuanced than the above quote suggests (he eventually suggested, for example, that section 33 should be amended to include a $60 \%$ raised majority requirement ${ }^{33}$ ). And thirdly, even if we did presume for the sake of argument that the preservation of legislative supremacy is a reasonable way of understanding the adoption of section 33 historically (a big leap, I would suggest), this would create a far deeper and more potent problem with the internal consistency of the Constitution Act.

This third point is pretty crucial, I think, so we should take a moment to follow it through. In this regard, an appropriate starting point is the distinction that the American constitutional theorist Bruce Ackerman makes between "levelling" ${ }^{34}$ democracies (e.g. the UK) and "dualist"35 ones (e.g. the United States and indeed, most other modern democracies - from Germany 
to India). In essence, the definitive point of distinction between such systems is that "levelling" ones allow all law, including constitutional law, to be amended via ordinary lawmaking procedures (e.g. majority votes across several legislative chambers), whereas "dualist" systems require that special, more arduous procedures are used for amendments to constitutional law.

To explain this further, in Ackerman's We the People trilogy, American dualism is defended in part on the grounds that it reflects an awareness of the fact that majoritarian representation is an always imperfect means of aspiring to the ideal of popular sovereignty (i.e. sovereignty of the people, rather than sovereignty of a popular majority or representatives thereof). On account of this manifest imperfection, Ackerman supposes that institutions of "ordinary politics" 36 should not be taken as sovereign or supreme over the most fundamental, constitutional matters of government. On the contrary, to the extent that a state's constitution is supposed to represent the fundamental decisions of the people taken as a whole, Ackerman insists that constitutional amendment should require a special but not necessarily fixed or formalized level of institutional and popular consent. This could mean many things - e.g. raised majorities, multiple majorities across time and space, etc. - but the key is that higher lawmaking, or constitutional lawmaking, should be a demanding and protracted business if a proposed amendment is to be counted not simply as an act of government, but as a manifestation of the "constituent power" 37 that, at least in the United States, is symbolically attributed to the people themselves (note the US Constitution's preamble, which attributes authorship to "We the People of the United States of America").

Fair enough, you might think. But where am I going with this? Or more precisely, what does American dualism have to do with the notwithstanding clause in Canada? My gambit is pretty simple: by laying out a special amendment formula for constitutional law, the Constitution Act fundamentally rejects levelling democracy, and simple legislative supremacy, in favour of dualism. ${ }^{38}$ To explain what I mean, while ordinary legislative majorities are presumed competent to represent the people of Canada and/or the various provinces on most issues, these legislative majorities are decidedly not sovereign or supreme under the Constitution Act, because they lack the legal right to exercise the people's constituent power by altering or abolishing the Constitution Act itself. ${ }^{39}$ In this regard, if section 33 is read as an attempt to preserve ${ }^{40}$ legislative supremacy in Canada, then one would be reading it as a contradictory attempt to backtrack on the overarching dualism of the Constitution Act and its special amendment formula. Of course, in one sense, this contradiction is intelligible, since it reflects the fact that the Constitution Act was a product of an uncomfortable compromise between levellers and dualists (not to mention the more specific fact that the notwithstanding clause was crowbarred in to ensure the agreement of Lougheed and the Prairie premiers). Should this contradiction be carried into the law, though? To my mind, the answer to this question should depend on whether an alternative, smoother reading is available. And on this point, one my ask: wouldn't the reading I offered in the previous section - a reading framing section 33 as giving rise to an exceptional tie-breaking power - fulfil this requirement?

Bearing this question in mind, here's the main point. If section 33 is viewed as an attempt to preserve legislative supremacy, then the implication is that the Constitution Act's framers simultaneously intended to bind and unbind ordinary legislative majorities to constitutional law, to limit their sovereignty at the same time as preserving it. By contrast, with a dialogic (or "institutional balancing") reading of section 33, we have something very different: namely, the grant of a limited, exceptional, temporary power to ordinary legislative majorities, although the means through which that power is limited are political - the so-called "notwithstanding taboo" 41 - rather than legal. The question, though - the question with which this article is concerned - is whether the notwithstanding clause would remain defensible in these terms if the political means of limiting the power it creates became ineffective, i.e. if the "notwithstanding taboo" started to fall on deaf, populist ears. My suggestion is that it wouldn't, which is to say 
that I view populism as a form of "chaos"42 to which section 33 can no longer properly apply, lest Canada slide into a situation of legislative supremacy that, as I have just argued, its 1982 Constitution Act rejects as a matter of basic principle.

\section{Conclusion: Section 33 in a Populist Future?}

To conclude now, if the notwithstanding clause keeps its current form, and if Müller-style populism were to become prominent or even normalized nationally or provincially, then Canada's constitutional future could well be bleak. Of course, if the recent experiences of the United States tell us anything, it is that a determined populist with a solid base and a deficient sense of shame can get away with a lot of democratically problematic behaviour, regardless of whether their constitution expressly grants them the power to derogate from core constitutional rights commitments. ${ }^{43}$ In this sense, one may wonder if there is really a difference between the United States, where an electorally successful populist movement can seize control of the Constitution through the crap-shoot of the judicial appointments process, for example, and Canada, where it can rely on the notwithstanding clause (at least for the duration of its time in power). Is the lesson of the new populist moment, the moment that we're currently living through, that democratic institutions depend in the final instance on whether we collectively value them enough to vote out their abusers? Is this the realpolitik truth of constitutional democracy: that its structures and strictures mean nothing at all when they mean too little to too many of $u s$ ?

This is true to a significant extent, but constitutional architects can still decide how hard an illiberal reform movement must work, and how shameless its proponents must be, to alter or circumvent judicially-determined constitutional law. To explain what I mean, think about the situation in the United States. If Roe $v$ Wade, ${ }^{44}$ for example, is eventually overruled or partially dismantled by the Roberts Court, it will have been a product of conservative activism across a very long generation, with Republican legislators in recent years using every tool at their disposal (e.g. "stonewalling" 45 Merrick Garland, the multiple failures of the Kavanaugh hearings, ${ }^{46}$ etc.) to bend the USSC in their favour. By contrast, if the US Constitution contained a majoritarian notwithstanding clause, it seems almost inevitable that abortion rights would have gone through a cycle of death and resuscitation from 1973 to the present. Of course, the elephant in the room in this debate is the question of judicial review's legitimacy, but there are good (and indeed, globally recognized) reasons for endorsing judicial review in general as a pathway to more sincere exercises of constitutional interpretation than may take place among legislators preoccupied with their reelection prospects.

In this sense, the critical question is: when an "apex" court issues a seemingly sincere interpretation of constitutional rights, at what point should we allow another institution whose sincerity is rightly questionable because of its function (and, precisely, because of its public accountability), to supersede that interpretation? Nothing in this question assumes that judicial decisions on constitutional rights are "infallible" 47 or apolitical, but it does assume that there are distinct benefits to allowing a politically independent and publicly unaccountable institution to take the lead, provisionally, on interpreting and enforcing constitutional rights. At the same time, though, these independent institutions can go badly wrong, and it will accordingly make sense to conclude, now, by briefly considering the wrongness of one of the most infamous periods of judicial activism in the country with the longest history of judicial review: the Lochner era in the United States. ${ }^{48}$

To frame it plainly and bluntly, the problem with the Lochner era was not that the USSC was interpreting the US Constitution incorrectly, or that it was chronically out of joint with the other branches of government. Rather, the problem with the Lochner era was that the Supreme Court remained recalcitrant when it was clear that the American people, by huge margins, were repeatedly repudiating its constitutional vision (as per Ackerman's reading in We the People: Transformations ${ }^{49}$ ). Suggesting that an override would 
have been appropriate in the context of the Lochner era is not the same as suggesting that an elected legislature should have the broad power to override judicial framings of constitutional rights by a simple majority. On the contrary, it suggests that extraordinary public support short of the requirement for a constitutional amendment, but far more than the requirement for ordinary legislative change - warrants the momentary rebuttal of the presumption that an independent court is optimally placed to interpret constitutional rights. Tellingly, one seems to find precisely this philosophy at work in the proposal of Senator Burton Wheeler, who suggested the following (purely federal) Congressional override clause as an alternative to President Roosevelt's proposal to effectively pack the USSC as a way of ending the Lochner era:

In case the Supreme Court renders any judgment holding any Act of Congress... unconstitutional, the question with respect to the constitutionality of such Act of provision shall be promptly submitted to the Congress for its action at the earliest practicable date that the Congress is in session...; but no action shall be taken by the Congress upon such question until an election shall have been held at which Members of the House of Representatives are regularly by law to be chosen. If such Act or provision is re-enacted by two-thirds of each House of the Congress... such Act or provision shall be deemed to be constitutional and effective from the date of such reenactment. ${ }^{50}$

By contrast, former Alberta Premier Peter Lougheed once suggested a more simple amendment to section 33 (as noted earlier): namely, placing a $60 \%$ raised majority requirement on its use. ${ }^{51}$ While Lougheed's proposal has the advantage of increased usability (and this really is an advantage if you accept that courts can be dangerous institutions too), Wheeler's has the advantage of requiring not simply raised support, but enduring and more plausibly considered support as well. Of course, if usage of the current, majoritarian clause has been rare, then there are good reasons for supposing that Wheeler or Lougheed-style formulae would be dead on arrival (i.e. completely unusable), but this may not be the case if Müller-style populist sentiments were to become more widespread and entrenched in Canada, thereby diluting the convention against override powers. The question is, do Canadians want to take the chance that, if a populist moment arrives - if it really arrives, as it has arrived in Poland, Turkey and the United States - their current system, based on a presumption of institutional comity, will survive it? I don't want to be too alarmist, but isn't this the time, in light of recent developments globally, to secure our democracies against the destructive forces of populist conceit? No institutional structure is watertight, but some are harder than others to blast through, and the current, majoritarian notwithstanding clause just isn't one of the more "blast-proof" options. ${ }^{52}$

\section{Endnotes}

* Postdoctoral Fellow, University of Alberta; Ph.D. (Luxembourg, 2017), LL.M. (Glasgow, 2012).

1 Canadian Charter of Rights and Freedoms, s 33, Part I of the Constitution Act, 1982, being Schedule B to the Canada Act 1982 (UK), 1982, c 11 [Charter].

2 Carl Schmitt, Political Theology: Four Chapters on the Concept of Sovereignty, translated by George Schwab (Chicago: University of Chicago Press, 2006) at 13.

3 Ibid. Unlike Schmitt, I will not be arguing that the termination of such a "normal" situation justifies the replacement of the otherwise applicable law with the rule of brute, sovereign power. If the normal situation presupposed by the notwithstanding clause were to lapse, then the appropriate response would be a constitutional amendment. It is precisely because such channels must be used that I suggest, in the concluding section of the paper, that the notwithstanding clause should perhaps be amended before a situational shift takes place, i.e. before it is too late. Whether one agrees with this will depend, I suppose, on whether one believes that populism is likely to take hold (or has already taken hold) in Canada or one of its provinces.

4 See e.g. Marco Revelli, The New Populism: Democracy Stares into the Abyss, translated by David Broder (London: Verso, 2019).

5 Jan-Werner Müller, What is Populism? (Philadelphia: University of Pennsylvania Press, 2016). 
6 See David Von Drehle, "Barack Obama Reveals His Populist Blindspot" (30 June 2016), online: Time <time.com/4389939/barack-obama-donaldtrump-populism/>. To selectively quote Obama's speech: "I'm not prepared to concede the notion that some of the rhetoric that has been popping up... [in the Trump campaign] is populist... Somebody who labels us versus them, or engages in rhetoric about how we're going to look after ourselves and take it to the other guy, that's not the definition of populism." In stark contrast with Obama's claim, Müller and many other political scientists would surely regard this as a historically apt definition of populism, although they may concede that Obama's speech was an admirable attempt to reframe the concept in liberaldemocratic terms.

7 See Müller, supra note 5 at 3.

8 See e.g. ibid at 61.

9 Ibid at 22.

10 Ontario Premier Doug Ford's use of the notwithstanding clause to push through his proposed cuts to Toronto City Council after a court judgment against him is probably the most plausible and recent example of Müller-style populism in Canada. For a sharp critique of Ford's actions, see Lorraine Weinrib, “Doug Ford Can't Apply the Notwithstanding Clause Retroactively to Impede Democracy" (18 September 2018), online: Globe and Mail <theglobeandmail.com/ opinion/article-doug-ford-cant-apply-thenotwithstanding-clause- retroactively-to/>.

11 See Schmitt, supra note 2 at 13.

12 Peter W Hogg \& Allison Bushell, “The Charter Dialogue between Courts and Legislatures (Or Perhaps the Charter of Rights Isn't Such a Bad Thing After All)" (1997) 35:1 Osgoode Hall LJ 75 [Hogg \& Bushell].

13 Richard Albert, "Advisory Review: The Reincarnation of the Notwithstanding Clause" (2008) 45:4 Alta L Rev 1037 at 1039 [Albert, "Advisory Review"].

14 Ibid at 1039 citing Sarah K Harding, "Comparative Reasoning and Judicial Review” (2008) 28:2 Yale J Intl L 409 at 433-434.

15 As noted above, the dialogue metaphor originated in the work of Peter Hogg and Allison Bushell (see Hogg \& Bushell, supra note 12), but it has been widely - though certainly not ubiquitously - embraced since then (see infra note 16). For a notable critique of Hogg and Bushell's perspective, see Ming-Sung Kuo, "Discovering Sovereignty in Dialogue: Is Judicial Dialogue the Answer to
Constitutional Conflict in the Pluralist-Legal Landscape?" (2013) 26:2 JL \& Jur 341.

16 For an example of the dialogue metaphor's influence on the Supreme Court of Canada, see Justice Iacobucci's opinion in Vriend v. Alberta [1998] 1 SCR 493, 156 DLR (4th) 385 [cited to SCR] especially at 565-566. For an example of another scholarly work which leans on the dialogue metaphor, see Kent Roach, The Supreme Court on Trial: Judicial Activism or Democratic Dialogue (Toronto: Irwin Law, 2001) at 174-204 [Roach, Supreme Court].

17 See Hogg \& Bushell, supra note 12.

18 See Christopher P Manfredi \& James B Kelly, "Six Degrees of Dialogue: A Response to Hogg and Bushell" (1999) 37:3 Osgoode Hall LJ 513 [Manfredi \& Kelly].

19 The idea of "balancing" judicial and legislative power is perhaps a better description of section 33's ideal function than the idea of promoting inter-institutional dialogue, although both notions aim at capturing something similar. To frame it simply, the key problem that I have with the dialogue metaphor is that the provisions of the Constitution Act that the metaphor points to don't allow for ongoing conversations over the interpretation of relevant rights. For example, while I will be arguing here that section 33 does a decent job of balancing legislative and judicial power in an appropriate political climate, its invocation essentially ends the judiciary's role in the conversation until the invocation lapses or is withdrawn (something which depends entirely on the legislature as an institution, although not on any particular group of electorally dispensable legislators). Moreover, as I argue in this section, a great deal of the dialogue metaphor's success actually rides on its applicability to section 33, since section 1 of the Constitution Act - which is often pitched as the key to dialogic readings of Canadian constitutional law - doesn't actually allow legislative input, at all, on the interpretation of constitutional rights (or on the proportionality of rights violations with legislative objectives).

20 See Hogg \& Bushell, supra note 12 and Roach, Supreme Court, supra note 16. See also Kent Roach, "Dialogic Review and its Critics" (2004) 23 SCLR 49.

21 Manfredi \& Kelly, supra note 18 at 523-524 [first instance of emphasis added, second instance of emphasis in original]. Although I accept and endorse Manfredi and Kelly's point here, one may perhaps turn a version of their own argument against them insofar as they describe legislators 
as "democratic actors" (ibid at 525), presumably in contrast with undemocratic judges. While there are of course important ways in which legislators possess superior democratic legitimacy to courts, it is an impoverished conception of democracy indeed which conflates majoritarian legislation with democracy itself. Perhaps this is not what Manfredi and Kelly intended, but there is surely a hint of this conflation every time someone juxtaposes the judicial and "democratic" branches of government. At the very least, don't modern courts play a critical role in securing modern democracy by safeguarding important democratic freedoms - freedoms to speak, vote, associate, etc. - against governmental abuse?

22 For Albert, the political convention against the use of the federal override power in particular is so strong that one may consider it to have slipped into "desuetude." However, I suspect that recent uses in Ontario and Quebec significantly undermine the application of this thesis, or anything close to it, to the provincial override. On the desuetude of the notwithstanding clause generally, see Albert, "Advisory Review", supra note 13 at 1041-1043. See also Richard Albert, "Constitutional Amendment by Constitutional Desuetude" (2014) 62:3 Am J Comp L 641 at 669-673.

23 See e.g. Richard McAdam, "The Notwithstanding Taboo" (2009) 6:1 Federal Governance 1.

24 See Ran Hirschl, Towards Juristocracy: The Origins and Consequences of the New Constitutionalism (Cambridge, Mass: Harvard University Press, 2004).

25 See e.g. Aaron Hutchins, "Why Doug Ford Went Straight to the Nuclear Option on Toronto City Council" (10 September 2018), online: Macleans $<$ macleans.ca/politics/why-doug-ford-wentstraight-to-the-nuclear-option-on-toronto-citycouncil/>.

26 I don't think it is controversial to suggest that a majority of contemporary constitutional scholars, and a majority of contemporary constitutional systems, accept quite a strong form of the presumption that judges are better equipped than legislators to interpret and enforce constitutional rights. In support of this trend, see Kai Möller, The Global Model of Constitutional Rights (Oxford: Oxford University Press, 2012). As I point out in the concluding section of this paper, I hold to a weak version of this presumption insofar as I assume that the presumption is rebuttable where large and/or enduring public (not simply legislative) majorities oppose judicial interpretations of constitutional rights. I hesitate, however, to offer specific suggestions here on when a majority is large or enduring enough to warrant overriding judicial interpretations of fundamental rights, or on how to ensure that support is meaningfully public, i.e. not merely institutional.

27 Zachary Smith, "Overriding the Constitution: Populism, the Notwithstanding Clause, and Its Implications for Canada's Rights Framework" (20 May 2019), online (blog): Kennedy School Review $<$ ksr.hkspublications.org/2019/05/20/overridingthe-constitution-populism-the-notwithstandingclause-and-its-implications-for-canadas-rightsframework $/>$.

28 See e.g. Michael Hirsh, "With Emergency Declaration, Trump Sticks by His Populist Persona" (14 February 2019), online: Foreign Policy <foreignpolicy.com/2019/02/14/withemergency-declaration-trump-sticks-by-hispopulist-persona/>.

29 On the situation in Poland see Wojciech Sadurski, "How Democracy Dies (In Poland): A Case of Anti-Constitutional Populist Backsliding" (2018) 1 Revista Forumul Judecatorilor 104.

30 See Müller, supra note 5 at 3.

31 "Preserve" is a loaded term here, because it seems to entail an assumption that legislative supremacy was a fundamental principle of Canadian law prior to 1982. Was this the case, though? For an argument against such claims, see Peter H Russell, "Standing up for Notwithstanding" (1991) 29:2 Alta L Rev 293 at 294-295 [Russell].

32 Reprinted in Peter Lougheed, "Why a Notwithstanding Clause?" (1998) 6 Points of View (published by the Centre for Constitutional Studies) at 3 [emphasis added]. Note the apparent strength of the word "supremacy" here; legislatures should not only have a meaningful say in the interpretation of constitutional rights, but should be supreme.

33 Ibid at 17.

34 One of Ackerman's first uses of the term "levelling democracy" was in Bruce A Ackerman, "The Storrs Lectures: Discovering the Constitution" (1984) 93:6 Yale LJ 1013 at 1035-1036. To quote Ackerman's definition: "In this single-track view, there is only one place in which the political will of the American people is to be found: the Congress of the United States. If the Congress enacts a law, the People have spoken; if not, not. It's that simple, and no talk about the problematics of representation should be allowed to obscure this fundamental reality" (ibid at 1035).

35 Ibid at 1039-1040. 
36 See Bruce Ackerman, We the People: Foundations, vol 1 (Cambridge, Mass: Harvard University Press, 1993) at 182. As Ackerman puts it, "no institution of ordinary politics can be allowed to transubstantiate itself into the People" (ibid at 182). The significance of the qualifying phrase "ordinary politics" is that extraordinary processes - processes which provoke extraordinary levels of public debate and participation over a significant period of time - can, for Ackerman, produce outcomes worthy of attribution to the people themselves (although this is still an act of attribution, or imputation).

37 On the notion of constituent power, see Martin Loughlin, The Idea of Public Law (Oxford: Oxford University Press, 2003) at 99-113.

38 My argument here comes close to Richard Albert's argument in Albert, "Advisory Review", supra note 13 , but with a small difference: namely, that whereas Albert focuses on the supremacy clause of the Constitution Act, I assume that the legal locus of Canadian sovereignty lies with the institutional plurality required to amend the Constitution Act (see ibid at 1048-1052). In this sense, I don't subscribe to Albert's claim that the "Charter is sovereign" (ibid at 1050) or that Canada is currently in a situation of "Charter sovereignty" (ibid at 1050). On the contrary, since the Constitution Act makes provision for its own amendment, it is clear that it doesn't situate itself at the top of the ladder, so to speak, but rather affirms the sovereignty of the Canadian people (or peoples), expressed (imperfectly, of course) through their use of the amendment formula.

39 I should point out here that I am not assuming a homogenous notion of the people, but take for granted that modern democratic states are indelibly marked by "the fact of reasonable pluralism" [see John Rawls, Political Liberalism (New York: Columbia University Press, 1993) at 4], and that democracy accordingly always involves the delicate attribution of decisions to a chronically inapparent popular sovereign.

40 Once again, I should note my awareness of the fact that there was not necessarily a constitutionally core, pre-1982 tradition of legislative supremacy to be preserved in Canada. See Russell, supra note 31.

41 See McAdam, supra note 23.

42 See Schmitt, supra note 2.

43 When it comes to "democratically problematic behaviour" generally, the evidence of the President's possible obstruction of justice in the Mueller Report is an obvious example. When it comes to possible violations of human rights and human dignity, there are countless instances worth flagging, from the singling out of Muslim-majority countries in the President's early term travel ban (his "complete and total shutdown of Muslims entering the United States," as Trump called it during his election campaign), to the abysmal and grievously inhumane conditions reported in migrant detention facilities along America's southern border. On the Trump administration's human rights record generally, see Sherrilyn Ifill, "President Trump's First Year was an Affront to Civil Rights" (17 January 2018), online: Time $<$ time.com/5106648/donald-trump-civil-rightsrace $/>$.

44410 US 113 (1973) [Roe].

45 See Daniel Epps \& Ganesh Sitaraman, "How to Save the Supreme Court," 129 Yale Law Journal [forthcoming in 2019) at 3.

46 Ibid at 6. See also Laurence Tribe, "All the Ways a Justice Kavanaugh Would Have to Recuse Himself" (1 October 2018), online: New York Times <nytimes.com/2018/10/01/opinion/justicekavanaugh-recuse-himself.html $>$.

47 As Peter $\mathrm{H}$ Russell puts it in his defence of the notwithstanding clause: "Judges are not infallible. They make decisions about the limits and nature of rights and freedoms which are extremely questionable." See Peter Russell, "Standing up for Notwithstanding” (1991) 29:2 Alta L Rev 293 at 295.

48 See Lochner $v$ New York 198 US 45 (1905). On the Lochner era more generally, see Cass R Sunstein, “Lochner's Legacy" (1987) 87:5 Colum L Rev 873.

49 See Bruce Ackerman, We the People: Transformations, vol 2 (Cambridge, Mass: Harvard University Press, 1998) at 279-382.

50 Reprinted in ibid at 321 [emphasis added].

51 See Lougheed, supra note 32 at 17.

52 I should also mention Richard Albert's "advisory review" reform here, which would constrain judicial power in Canada by requiring a unanimous verdict for a law to be invalidated on constitutional rights grounds (a mere majority will only be "advisory," like under the UK's "declarations of incompatibility" system for human rights adjudication). While I find Albert's proposal compelling, it would be inappropriate, I suggest, in a populist context, which requires the modest dilution of legislative rather than judicial power (as I have suggested immediately above). See Albert, "Advisory Review", supra note 13 at 1060-1063. 